\title{
Do Entrepreneurs Really Create Entrepreneurial Cultures? When Intentions do not Match Actions
}

\author{
Seçil Bayraktar* \\ Özyeğin University
}

\begin{abstract}
From the perspective that organizational cultures are shaped by their founders, it is expected that entrepreneurs create entrepreneurial cultures in line with their innovative approach. This paper challenges this expectation by drawing attention to the relationship between entrepreneurs and the cultures they build, with a particular emphasis on the potential challenges that may inhibit entrepreneurs from forming and maintaining innovation oriented cultures as intended. Four traps, identified as the trap of control, the trap of similarity, the trap of preservation, and the trap of individual identity, that act as barriers in the formation of innovative cultures are proposed and discussed in relation to the current literature.
\end{abstract}

Keywords: entrepreneurship, creativity, innovation, organizational culture

\section{Girişimciler Gerçekten Girişimci Kültürler Yaratır mı? Niyetler ile Davranışlar Eşleşmediğinde}

\section{Özet}

Örgütsel kültürlerin, kurucuları tarafından şekillendirildiği düşünülürse, girişimcilerin, kurdukları örgütlerde, yenilikçi yaklaşımları ile inovatif (girişimci) kültürler oluşturmaları beklenmektedir. $\mathrm{Bu}$ makale, bu beklentiyi sorgulayarak, girişimcilerin, niyet edildiği gibi yenilikçi kültürler oluşturup korumalarının önünde yer alan bazı engeller var olduğunu öne sürmektedir. Buna bağlı olarak, girişimcilerin, yenilikçi örgütsel kültürler oluşturmalarının önünde yer alan dört tuzak (kontrol tuzağı, benzerlik tuzağı, muhafaza etme tuzağı, ve bireysel kimlik tuzağı) tanımlanmış ve mevcut yazın ile bağlantılı olarak ele alınmıştır.

Anahtar Kelimeler: girişimcilik, yaratıcılık, inovasyon, örgütsel kültür

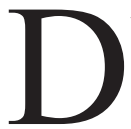
ue to the immense effects of globalization, technological advances, and increasingly competitive environments, innovation has become a requirement for organizations in order to respond to constantly changing market demands and customer needs (Shimizu and Hitt, 2004). In this respect, innovation has gained

\footnotetext{
* Seçil Bayraktar is an Assistant Professor at the Faculty of Business at Özyeğin University, Nişantepe Mahallesi. Orman Sokak. Çekmeköy 34794, Istanbul Turkey. E-mail: secil.bayraktar@ozyegin.edu.tr
} 
further importance for the competitive advantage and more, crucially, for the survival of organizations (Capaldo et al., 2003). According to Heunks (1998), the chances of a small firm to survive and to be successful are becoming ever more dependent on innovation. Consequently, this had led practitioners and scholars to identify the factors that stimulate creativity and innovation in organizations.

There is a close linkage between entrepreneurship and innovation. Entrepreneurship is traditionally viewed as the creation of something new that did not previously exist, and thus as a creative act and innovation (Gartner, 1988; Schumpeter, 1934). Entrepreneurial acts are characterized by searching for new challenges and focusing on continuous innovation in order to sustain business success and competitive advantage (Drucker, 1985; Russell and Russell, 1992; Zhao, 2005). Furthermore, the entrepreneur is mainly characterized by innovative behaviour (Gartner, 1988). Schein (1983) posits that organizational cultures are formed primarily by their founders. The founder of a firm by definition is an entrepreneur and innovator (Heunks, 1998). Thus, it is typically expected that entrepreneurs, who are characterized to be flexible, creative, independent, and open to new ideas with their innovative approaches and entrepreneurial enthusiasm (Cardon et al., 2009; Heunks, 1998), shape their organizational culture in line with their beliefs and values. Accordingly, fostering creativity that lead to implementation of innovations should be a typical aspect in entrepreneurial cultures.

However, the outcome may not always be as intended. Slevin and Covin (1990) argue that the entrepreneur's managerial behavior is not sufficient for success if the organization does not have the appropriate culture to support such behavior. Thus, the ability to create a culture of innovation is also necessary (Zhao, 2005). However, despite the expectations, there might be constraints and inhibitors to the effective formulation of an entrepreneurial culture caused by the entrepreneurs themselves.

This conceptual paper, essentially touching upon the dark side of entrepreneurship, anticipates challenging the natural expectation that entrepreneurship and entrepreneurial cultures go hand in hand. More specifically, this paper investigates the relationship between entrepreneurs and the cultures they create and emphasizes potential factors that may inhibit entrepreneurs from forming and maintaining entrepreneurial cultures as intended. Four different potential traps derived from the literature; specifically the trap of control, the trap of similarity, the trap of preservation, and the trap of individual identity, associated with the entrepreneur's actions that act as barriers in formation and sustaining of innovative cultures are proposed by the author and discussed in relation to the literature.

This paper has particular significance since it addresses a major gap in the literature. Dunne and colleagues (2016) assert that while entrepreneurship research often focuses on innovation and creativity, little is known about how entrepreneurs create an environment that enhances innovation. Researchers point to the need for studies on factors that determine a culture that supports creativity and innovation (Judge et al., 1997; Martins and Terblanche, 2003). In addition, the majority of the research has focused on the bright side of entrepreneurship. While previous research has documented some of the dysfunctional outcomes of the dark side, the impact of entrepreneurial actions 
on creativity and formation of entrepreneurial cultures has not been examined in detail or has remained rather fragmented.

Furthermore, considering that innovation is crucial for the survival and success of entrepreneurial organizations (Kang et al., 2015), research on the subject is specifically needed in the entrepreneurial context. This study contributes to the aforementioned gaps in the literature in the intersection of entrepreneurship and entrepreneurial cultures.

The next section explains the relationship between entrepreneurs and entrepreneurial cultures, followed by a review of work on the dark side of entrepreneurship. Then, the four traps that inhibit entrepreneurs from forming entrepreneurial cultures are proposed and discussed.

\section{Entrepreneurs and Entrepreneurial Cultures}

The concept of entrepreneurship cannot be reduced to a single definition. It can focus on the creation of new businesses or it can occur within existing organizations, thus encompassing multiple definitions including intrapreneurship, corporate entrepreneurship or social entrepreneurship. However, creating new ventures is probably the most commonly used context in which to address entrepreneurs. Schumpeter (1934) defines an entrepreneur as a person who carries out new combinations such as new products, processes, markets, or organizational forms. Entrepreneurship is the creation of a new venture based on an innovative idea or a renewal and innovation in an existing system (Gartner, 1988). According to Gartner, research on entrepreneurship should focus on the actions of the entrepreneurs (what the entrepreneur does) rather than the traits (who the entrepreneur is). This paper also draws from the behavioral theory of the entrepreneur and focuses on the entrepreneurs' actions while they form the organizational culture of a new venture.

Entrepreneurs' actions have been positively related to innovation in literature. Schumpeter's (1934) concept of creative destruction describes entrepreneurs as sources of disequilibrium who destroy the equilibrium by means of altering old ways of doing things through continuously responding to change, shifting resources, creating new alternatives, and constantly innovating. Furthermore, entrepreneurial ventures are often characterized by a context of innovation where the entrepreneur is expected to promote idea generation, idea structuring, and idea promotion (Cogliser and Brigham, 2004). According to Yamada and Yamashita (2006), an entrepreneur, as the founder, is influential in nurturing and supporting creativity and innovation ${ }^{[1]}$ (Shalley and Gibson, 2004; Yamada and Yamashita, 2006).

[1] For the clarity of concepts, it would be useful to note that in many studies creativity and innovation are usually used interchangeably. In fact, they are highly related but are different constructs. Creativity is defined as a combination of flexibility, originality and sensitivity to ideas, enabling the thinker to break away from the usual sequence of thought (Jones, 1972). On the other hand, innovation is defined as "the intentional introduction and application within a role, group or organization of ideas, processes, products or procedures, new to the relevant unit of adoption, designed to significantly benefit the individual, the group, the organization or wider society" (West and Farr,1990: 9). Creativity is the first step in the innovation process (Amabile, 1988; West and Farr, 1990) and innovation is broader than creativity by also including the successful implementation of ideas (Amabile, 1996; Baer, 2012; King and Anderson, 2002). However, regardless of the type of innovation (e.g. process, service, product, strategy), innovation presupposes the existence of creativity. Therefore, while the concepts of creativity and innovation are both used, this paper focuses mainly on the creativity aspect of innovation since creativity is a prerequisite of innovativeness, and thus of entrepreneurial cultures. 
This is also supported by Schein's model of organizational culture. The culture that the entrepreneur creates is crucial because culture is strongly related to creativity and innovativeness (Burnes, 1996; Kao, 1989; Nystrom, 1990; Pohlmann et al., 2005). According to Schein (1985), organizational culture is made up of a pattern of shared, taken-for-granted assumptions that are held by the members of an organization and taught to the new members. When a culture is created, the founder or the entrepreneur is granted a fundamental role of setting the roots of the culture (Schein, 1983; 1985). Pettitgrew (1979) refers to the founder-entrepreneurs as creators of cultural components such as beliefs, ideologies, and symbols. Founders can develop and maintain an organizational culture of innovation by creating and spreading a set of values that reinforce these cultural attributes (Trice and Beyer, 1993). In line with that approach, it would be expected that entrepreneurs will create entrepreneurial cultures in the ventures they form.

Some common attributes of entrepreneurial cultures can be summarized as focus on people and empowerment, teamwork, freedom to try and fail, experimentation, risk taking, creativity, innovation and change (Jassawalla and Sashittal, 2002; Peters, 1997; Timmons, 1999). In Quinn and Rohrbaugh's (1983) Competing Values Framework, adhocracy is defined as a form of entrepreneurial culture where there is high commitment to seeking new challenges, and knowledge, experimentation and innovation and innovative leaders encourage members to take risks. Mintzberg (1979) also refers to adhocracy as a truly innovative organizational form, being a fluid and highly organic structure with little formalization of behavior. The leadership styles of such cultures are characterized as entrepreneur, innovator and risk taker (Cameron and Quinn, 1999).

Based on the aforementioned connection of entrepreneurship, creativity and entrepreneurial (innovative) cultures, it is expected that entrepreneurship and entrepreneurial cultures go hand in hand. In an entrepreneurial culture, organizational values and practices need to be consistent in order not to convey confusing messages (Argyris and Schön, 1974). Consequently, an entrepreneur's innovation related values should be reflected in the organizational practices so that there is no incongruity. However, this paper challenges this expectation by referring to some potential challenges faced by the entrepreneurs. In other words, the entrepreneurs' actions in their daily organizational practices may not follow their intentions to create and maintain an entrepreneurial culture. These challenges are mainly associated with what is called the "dark side" of entrepreneurship.

\section{Dark Side of Entrepreneurship}

Several researchers have also examined what they refer to as the dark side of entrepreneurship in order to draw attention to dysfunctional attributes of entrepreneurship (Beaver and Jennings, 2005; Fisher and Langan-Fox, 2009; Kets DeVries, 1985; Kuratko, 2007; Miller, 2015). Referring to the dark side, Kets DeVries (1985) argues that entrepreneurial perspective may also have a destructive source in the drive of the entrepreneur. Accordingly, the way entrepreneurs manage the challenges of risk, stress, and entrepreneurial ego can be potentially destructive. The strong desire to control their business may lead to an obsession for autonomy and over control. In addition, ego may lead to too much 
optimism and cause unrealistic judgments when faced with critical decisions. Beaver and Jennings (2005) also suggest that entrepreneurs may display egocentric attitudes associated with the abuse of power in their hands, which may lead to the failure of the business. Fisher and Langan-Fox (2009) refer to the obsessive passion associated with entrepreneurship and point to both positive and negative outcomes of this passion. Accordingly, the dark side of obsessive passion results in poor self reflection, less adaptability, ineffective relationships and failures in business decision making. This paper also raises concerns regarding the dark side associated with dysfunctional outcomes of entrepreneurs' actions related to failure to create an entrepreneurial organizational culture.

\section{What Inhibits Entrepreneurs from Creating Entrepreneurial Cultures?}

From the functionalist perspective, it is well documented in literature that founders and leaders of organizations affect their organizations' cultures and structures by embedding their own values (Schein, 1985; Schneider, Goldstein, and Smith, 1995; Trice and Beyer, 1993). This assumption also leads us to envisage that entrepreneurs are likely to impose their own values and innovative styles on the culture they create. However, the actions of entrepreneurs may sometimes lead to unintended consequences and turn out to be destructive rather than constructive in terms of creating or maintaining an entrepreneurial culture.

Drawing from the behavioral theory of entrepreneurs (Gartner 1988, 1990) and Schein's model of organizational culture, this paper investigates the actions of entrepreneurs, as the founders of a new culture, that inhibit them from forming entrepreneurial cultures. The paper proposes four potential traps that the entrepreneur may get blinded by. They are called the trap of control, the trap of similarity, the trap of preservation, and the trap of individual identity. Each of these potential failures is also named from the view of the entrepreneur as "My Command", "My Worldview", "My Best Way", and "My Organization" respectively.

\section{1. "My Command": Trap of Control}

Among portrayal of entrepreneurs, it is generally acknowledged that entrepreneurs tend to prefer autonomy implying self-reliance, dominance, and independence, and they have a low need for support which can lead to delegation and communication problems (Rauch and Frese, 2007; Sexton and Bowman, 1985). Kets DeVries (1985) also emphasizes the dark side of entrepreneurs as a strong desire to control their business, which may lead to obsession for autonomy and over control.

Entrepreneurs come up with a brilliant idea; they have the ability to turn this creative idea into an innovation and expand their business upon it (Reich, 1987). However, this may bring along some kind of ownership of the business or idea as well. It can be the need to control, or the need for autonomy, or it can be the lack of trust in others' competence (Kets De Vries, 1996), feeling that nobody else can own and protect the business as much as he or she. Feldman (1993) found that perfectionism and over com- 
mitment to ideals can reflect on an inner-directed cultural orientation, which results in the tendency to control. This may result with the tendency of over-controlling and the failure to give initiative, or in other words, failure to empower other members of the organization. However, entrepreneurial cultures and their essential element, creativity, are fostered via empowerment. That is also supported by the finding that participative leadership is related to cultures of innovation (Ogbonna and Harris, 2000).

The literature provides adequate evidence regarding the positive association of empowerment to creativity and innovative cultures. Empowerment has been identified by many researchers as being one of the most important factors that influence employees' creativity and innovativeness (Burpitt and Bigoness, 1997; Dooley and O'Sullivan, 2000; Frischer, 1993; Krause, 2004; Spreitzer, 1995). According to DeJong and Den Hartog (2007), one way for organizations to become more innovative is to capitalize on their employees' ability to innovate. They found that delegation by giving subordinates sufficient autonomy to make decisions was positively linked to idea generation and innovation application behavior.

Encouragement of risk-taking, idea generation, a collaborative idea flow and participative decision making are positively related to innovative cultures (McLean, 2005), since people are likely to produce unusual ideas when they are encouraged to do so and when they feel free to experiment (Parnes, 1961). Blumentritt, Kickul, and Gundry (2005) found that in order to develop innovation oriented cultures, entrepreneurs need to encourage and extract contributions from other individuals in the organization by involving them in the idea development stages. This way, creativity in the organization does not solely depend on the creative potential of the entrepreneur.

However, despite the affirmed relation between empowerment and creativity, at the early stage of the firm, it can be shown that some entrepreneurs may have the tendency of not letting go of their control and of micro-managing others' business (Kets De Vries, 1996). Until some point in time, they try to settle things, set up strategies, and make decisions on their own. Although this might have advantages such as fast and centralized decision making and responding quickly to changing situations, in the long run this causes major problems of leader dependence (Kark et al., 2003). These types of entrepreneurs, seen as the leaders in the organization, control and take initiative so much, that by failing to give the initiative to others, the other members develop dependence on the leader's opinions and decisions. Dependence on the leader manifests itself such that employees are limited in their ability to make decisions without the leader's guidance (Kark et al., 2003). Consequently, they may feel it unnecessary to take initiative in decisions and make creative contributions, since the leader already takes care of everything; this may result in cognitive laziness (Shah and Oppenheimer, 2008).

After this initial stage of settling down, if the entrepreneur feels the relief that the organization has now settled its core and the people involved are also capable of continuing the organization's mission, he may believe that it is time for empowering the others to take initiative. However, at this point, the employees, who have developed leader dependence over time, feel stressed when faced with an empowered situation which they were not used to before. However, in contrast to leader dependence, empowerment 
requires employees' autonomy, independence, and self-efficacy (Kark et al., 2003). The literature suggests that when there is a dependency on the leader, the departure of the leader (or withdrawal from full control in this particular case) may result in the followers' feelings of distress (Shamir, 1991). Moreover, from the perspective of the employees, this situation may be regarded as a change event in their role or task, causing an uncertain environment where they are not sure as to how to respond. The literature of change suggests that change events combined with uncertainty lead to stress (Lazarus and Folkman, 1984; Rafferty and Griffin, 2006). Consequently, stress is associated with decreased creativity (Talbot et al., 1992). Therefore the positive relationship expected between empowerment and creativity turns into a negative one.

When the employees have developed a dependence on the leader due to the previous behaviors of the entrepreneur, the employees' sense of competence and self efficacy are also reduced. Feeling no competence regarding taking initiative, stress emerges as an affective reaction for coping with a new and unexpected situation (Parker, 1998). Consequently, the stress lowers their creative abilities and reverses the positive empowerment-creativity relationship towards a negative one.

It can be summarized that after periods of over control by the entrepreneur, if subordinates develop dependence on the entrepreneur leader, they will experience feelings of stress when they are empowered to take initiative, which will decrease their creativity. Hence, considering the negative impact on innovation, entrepreneurial action emphasizing too much control with little empowerment at the initial stages of business can be proposed as the first failure that prevents the creation of entrepreneurial cultures. It is named the trap of control, or from the entrepreneur's perspective, the trap of overemphasizing "my command".

Proposition 1: Control is positively related to leader dependence.

Proposition 2: Control is negatively related to empowerment.

Proposition 3: Stress mediates the relationship between empowerment and creativity.

Proposition 4: Leader dependence moderates the relationship between empowerment and stress. In other words, empowerment will lead to more stress if employees have more leader dependence.

\section{2. "My Worldview": Trap of Similarity}

Previous research shows that founders of organizations are directly influential on the creation of organizational cultures by embedding their own values, beliefs and assumptions (Schein, 1985; Schneider et al., 1995). Schneider (1987) also asserts that "people make the place," implying that people in the organization determine the organizational culture and practices. In line with this proposition, he put forward the Attraction-Selection-Attrition (ASA) framework. Attraction means that people's preferences to work in an organization depend on the congruence of their own values with 
those of the organization (Schneider et al., 1995). Selection indicates that leaders hire people who share the same values and assumptions. Finally, attrition posits that people whose values do not fit the values of the organization tend to leave it.

Focusing on the selection process of the ASA framework, leaders and founders of an organization create cultures by reflecting their own values. As a result, the entrepreneurs will be likely to select those applicants who are congruent with his or her ideas and beliefs to work with. Pettigrew (1979) also mentions that entrepreneurs may initially recruit their employees based on prior acquaintance and homogeneous backgrounds. This may seem to be an ideal way of creating an entrepreneurial culture with personal values being congruent with the value systems of the entrepreneur. Although this congruence may also have beneficial outcomes in terms of group harmony and cohesion, Schneider and colleagues (1995) argue that there is an unintended consequence of the ASA process in terms of increasing homogeneity in the organization, called the homogeneity hypothesis.

As mentioned before, adhocracies are interpreted as the ideal innovative cultures. The foremost strength of the adhocracy is its ability to bring together experts from various fields, and merge them as ad hoc project teams to solve new and unexpected problems. In order to boost innovation, the building of knowledge and skill requires the combination of different people and a diversity of values and opinions (Mintzberg, 1979). Diversity refers to the extent of the similarity or dissimilarity of members of a team along different attributes, such as gender, age, education, ethnicity, culture, and functional experience (Jackson, May, and Whitney, 1995). Researchers suggest that diversity is an important facilitator of creativity with the generation and communication of diverse perspectives (Amabile, 1996; Woodman et al., 1993). Multiple perspectives may boost innovation via increasing the information available for problem solving and enhancing the team's ability to create alternative interpretations and generate creative solutions to problems (Hennessey and Amabile, 1998; McLeod, Lobel, and Cox, 1996; Watson, Kumar, and Michaelson, 1993).

As opposed to the view of Schneider et al. (1995), which regards homogeneity as an unintended consequence, some other researchers are proponents of homogeneity over heterogeneity in teams. According to Blau (1977) firms characterized by high levels of cultural diversity experience dissimilar dynamics. In culturally homogeneous groups, members share their worldviews, have higher attachments to the group, communicate with each other more often, and experience less conflict (Earley and Mosakowski, 2000; Williams and O'Reilly, 1998).

The role of the entrepreneur is thus to be aware of the limitations of each perspective and create the balance between diversity and conflict. The entrepreneur, while forming the innovative culture, needs to use the advantages of heterogeneity in terms of fostering creativity and minimize its disadvantages by working on conflict resolution strategies and maintaining the harmony and open communication in the group.

Considering the homogeneity hypothesis, the second failure that inhibits developing innovative cultures is related to the similarity-based selection processes of entrepreneurs and is proposed as the trap of similarity; or from the entrepreneur's perspective, the trap of "my worldview". 
Proposition 5: Similarity of values in the organization (low diversity) reduces creativity.

\section{3. "My Best Way": Trap of Preservation}

Although entrepreneurs are portrayed as proactive and innovative risk takers who always search for change and use it as an opportunity (Drucker, 1985; Schumpeter, 1934), they may fail to demonstrate such a big embrace of change in their actions. This can be attributed to their paradox between change and preservation (Baden-Fuller and Volberda, 1997). It is proposed that the tendency to prefer preservation over change may be caused by two major reasons; feelings of ownership or fear of failure.

Entrepreneurs, as the owners of the business may feel a strong ownership towards their business and the original idea they have implemented such that their idea becomes a monument to them (Conger, 1990). As Kets DeVries (1985) mentions regarding the dark side, entrepreneurs have a certain ego which can be destructive, if not used in a positive way. For example, their ego may lead to a cognitive bias in their decision making which leads to an unrealistic optimism about the probable success of their ideas (Dawson and Henley, 2012). In that respect, Camerer and Lovallo (1999) and Vecchio (2003) also found that entrepreneurs tend to overestimate their chance of success since they are over confident about their own abilities. If the necessary change requires that the entrepreneur modify the business or even discard an important portion of it for something better, the entrepreneur may let the feelings of attachment to his or her idea overwhelm him or her. Thus, when the subjectivity of ownership overcomes the objectivity of need for change, the entrepreneur may be blinded and be unable to make the effective decisions (Conger, 1990). The strong ties to the business may decrease the openness to change, which is a hindrance for an innovative culture that is seeking change.

Feelings of ownership can also be explained via the entrepreneur's passion. Passion is explained as a strong desire for a self-defining activity that one loves and in which requires a significant amount of time and energy (Vallerand et al., 2003). Cardon, Wincent, Singh, and Drnovsek (2009) state that passion is aroused in entrepreneurs since they do something that relates to a meaningful and valuable self-identity for them. According to Vallerand et al. (2003) passion is dualistic in nature; it is either harmonious or obsessive. Harmonious passion in an activity is more flexible. However, in the obsessive type, the activity may take control of the individual and lead to a rigid persistence in the activity even at high costs such as business failures or damaged relationships (e.g. escalation of commitment) (Fisher and Langan-Fox, 2009; Staw, 1981). In the context of this paper, an entrepreneur's obsessive passion may lead to insisting on rigid ideas with the aim of preserving them at the cost of giving up innovativeness and openness to change.

The second reason for change resistant actions may be attributed to the fear of failure. Entrepreneurs start their business based on their brilliant idea and take subsequent steps to make sure their business is a success. On the pathway of making decisions, after consequent success stories, entrepreneurs may face the fear of failure with the next moves. The initial success may persuade the entrepreneur that his ideas are invincible (Conger, 1990). Therefore, trusted and proven strategies become preferred over and 
over. In that case rather than trying and testing new strategies, the past patterns begin to create path dependencies. Becoming bound to a suboptimal course of action over time is also called entrapment (Drummond, 2004). Consistently, the employees are not provided the grounds for testing and experimenting, which is a prerequisite of creativity and innovation. As a result, this sacrifice of creativity for the fear of change reduces openness to change, and surely contradicts the innovative nature of entrepreneurship.

The trap of preservation also reduces the strategic flexibility of the firm. Shimizu and Hitt (2004) define strategic flexibility as an organization's capability of being aware of the changes in the external environment and taking appropriate actions in a timely and quickly manner. In turbulent environments, firms need to develop a unique set of resources, referred to as core competences, to build a competitive advantage (Hitt et al., 1998). These core competences must be continually developing rather than remaining static. Otherwise, in the absence of strategic flexibility, these core competencies of the firm face the danger of turning into core rigidities in highly competitive environments (Gilbert, 2005; Leonard-Barton, 1992; Prahalad and Hamel, 1990). The trap of preservation accompanied by reduced flexibility will hence develop core rigidities, which will be related to a decrease in creative potential.

Bearing in mind that the tendency of preservation is a threat to an entrepreneurial culture, the entrepreneurs need to be aware of the balance between preservation and change. This can be managed by ambidexterity (Gupta et al., 2006). Ambidexterity is the ability to keep a balance between explorative and exploitative processes (Levinthal and March, 1993). March (1991) makes the distinction between the two concepts in that exploitation means using and developing things that are already known, whereas exploration refers to searching for new alternatives, experimentation and innovation. March (1991) further describes exploitation by the keywords of "refinement, choice, production, efficiency, selection, implementation, execution" and contrasts it to exploration which is described by terms such as "search, variation, risk taking, experimentation, play, flexibility, discovery, innovation”. Birkinshaw and Gibson (2004) and Volery and colleagues (2015) propose that the success of an entrepreneurial organization depends on ambidexterity (i.e. the balance of focus on the value of current business activity and searching for new value by innovation). Ambidexterity is seen crucial to innovation because innovation needs both explorative and exploitative aspects. Therefore it is important for the entrepreneur to focus on both of these processes.

On the other hand, if past success rewards using exploitation over exploration and if path dependencies are created due to a fear of failure, the culture becomes more risk averse which is not an aspect of entrepreneurial culture. March (1995) also points to this threat by stating that activities of exploration in startup firm fade away after a while and new ideas become standardized and routine. Thus, unless ambidexterity is properly managed, the trap of preservation inhibits creativity and the creation of an entrepreneurial culture.

Proposition 6: Tendency of preservation is negatively related to creativity and entrepreneurial culture. 
Proposition 7: Openness to change and strategic flexibility mediate the relationship between tendency of preservation and creativity and entrepreneurial culture.

\section{4. “My Organization”: Trap of Individual Identity}

The last proposed inhibitor of the formation of an entrepreneurial culture is over emphasis on the individual identity of the entrepreneur versus a focus on collective identity. A major prerequisite of a creative and innovative-supportive culture is teamwork and collaborative orientation (Gupta et al., 2004; Jassawalla and Sashittal, 2002). Creativity is fostered not only via the flexible and flat structures consisting of teams, but also by the positive climate enhanced by team spirit. Collective identity - sometimes used interchangeably with the term social identity - is defined as the identity that is shared with a group of others who have some common characteristics (Ashmore et al., 2004). Collective identity should be differentiated from self- identity, such that self-identity focuses on an individual's personal traits and attributes which distinguish one from the others (Banaji and Prentice, 1994). On the other hand collective identity depends on the extent to which an individual perceives himself or herself to be a member of a group and the significance attributed to this membership (Tajfel, 1978).

The literature presents evidence that members of a group identify more strongly with the collective identity of their group if the leader represents the collective identity and is perceived to be group prototypical (Van Knippenberg et al., 2004). Creating a culture that emphasizes the "us" approach versus the "me" approach is important for creating an entrepreneurial culture. However, sometimes the identity of the entrepreneur as the owner of the organization and the idea is so overwhelming that the entrepreneur is perceived as a hero who is not easy to approach and whose identity constitutes the organization.

In line with that, some studies have portrayed the entrepreneur as a hero (e.g. Boswell, 1972). Reich (1987) points to the myth of "entrepreneurial hero" that is a powerful image representing individual freedom, creativity, and inspiration. However, he further points to the need to emphasize collective versus heroic effort and argues that entrepreneurship should be a capability that diffuses throughout the organization, allowing for experimentation and development and leading to a collective capacity to innovate. Otherwise, when the entrepreneur plays the central role, the rest of the work force becomes solely the supporting cast where they become unable to perform without directions from above (Reich, 1987).

The "hero" perception can act as a barrier for representing the collective identity, and focuses more on the self-identity. As entrepreneurs are characterized by having a considerable amount of ego and a desire for applause (Kets DeVries, 1985, 1996), this tendency to promote individual identity may lead to an over emphasis of the entrepreneur's achievements rather than attributing the achievements to the organizational members as a team working together for a common purpose. Pettigrew (1979) also argues that the essential problem in entrepreneurship is the translation of individual drive into collective purpose and commitment. In this sense, if the collective identity is poorly constructed by the entrepreneur, the organization may be perceived as "the 
entrepreneur's organization" versus "our organization". At this point, it's in the hands of the entrepreneur to shape the culture around the identity of this heroic individual or not.

Furthermore, if the leader is perceived as a hero and idealized excessively, negative aspects are ignored creating the danger of "Yes people" around the leader, leading to group think in line with the tendency to agree with the leader's ideas, and consequently distorting decision making and creative thinking (Conger, 1990, Janis, 1971; Jaussi and Dionne, 2003).

While arguing for the importance of connective leadership, Lipman-Blumen (1992) refers to the ego-ideal of the American entrepreneur (Drucker, 1985). Accordingly this heroic figure is referred to as a self-reliant individual who has a trouble collaborating, believing others can do it as well, making synergetic group work and taking pride in others' success. Individualistic leaders usually do not possess these aspects of connective leadership. On the other hand, in connective leadership, egocentrism is replaced with mutuality (Lipman-Blumen, 1992). Consequently, it becomes crucial for entrepreneurs to emphasize more collaboration, collective achievement, teamwork and shared power across the organization, rather than positioning oneself as the hero, in order to foster an entrepreneurial culture.

Proposition 8: Focus on the individual identity of the entrepreneur is negatively related to creativity and entrepreneurial culture.

Proposition 9: Collective identity mediates the relationship between focus on the individual identity of the entrepreneur and creativity and entrepreneurial culture.

\section{Proposed Model of the Study}

Figure 1 illustrates the proposed relationships between the entrepreneurial acts associated with the relevant potential traps. Also it demonstrates the unintended consequences of these acts in the formation and maintenance of entrepreneurial cultures, directly and indirectly through their impact on creativity. Trap of control leads to leader dependence, which causes employees' feelings of stress in the case of empowerment. Consequently this stress reduces creativity and thus has a negative impact on creating an entrepreneurial culture. Trap of selection based on similarity of values reduces diversity in the organization, which again hinders formation of an entrepreneurial culture by lowering the potential of creativity in the organization. Trap of preservation relates negatively to creativity and entrepreneurial cultures by decreasing openness to change and strategic flexibility. Finally, trap of individual identity focus reduces collective identity, and thereby relates negatively to creativity and an entrepreneurial culture. 
Figure 1

Potential Traps Associated with Entrepreneurial Actions and their Consequences

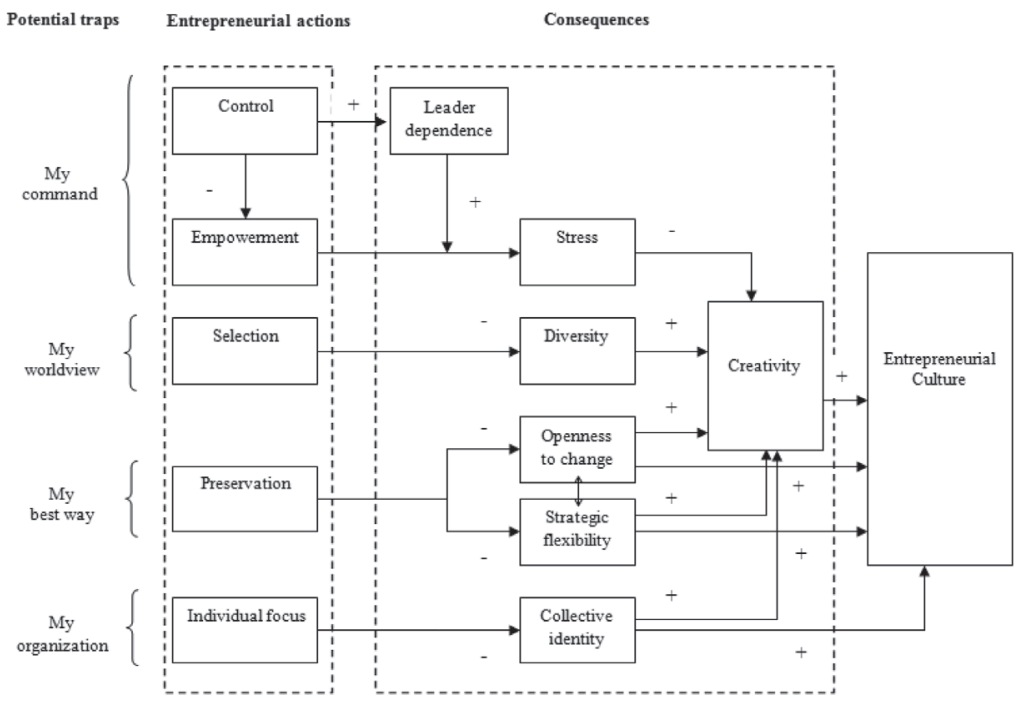

\section{Theoretical and Practical Implications and Suggestions for Future Research}

Innovation is crucial for the survival and competitiveness of organizations. While entrepreneurship research often focuses on innovation and creativity, little is known about how entrepreneurs create an environment that enhances innovation. Entrepreneurial culture of a new venture is an important aspect of an environment which enables innovativeness. Drawing from the behavioral approach of entrepreneurship and Schein's model of organizational culture, this paper questions the expected linkage between entrepreneurs' actions and their creation of entrepreneurial cultures. To do so, it points to the possible entrepreneurial actions which can be destructive to creativity and innovativeness, thus turning out to be inhibitors of entrepreneurial culture. While previous research has documented some of the dysfunctional outcomes of the dark side of entrepreneurship, the impact of entrepreneurial actions on formation of entrepreneurial cultures has not been examined in detail or in an integrated framework. This paper, with its proposed model, brings an extended view to the dark side of the entrepreneurs' actions and contributes to the scholarly literature on the entrepreneurial challenges of creating innovative cultures.

Furthermore this paper aims to provide practical implications to guide entrepreneurs in their actions while forming their organizations' cultures. Accordingly, entrepreneurs need to be aware of four potential traps, namely the trap of control, the trap of similarity, the trap of preservation, and the trap of individual identity. Although it does not mean all entrepreneurs will be caught in the traps identified, it is important to be aware that positive intentions may end up with unintended consequences, or even threats to the 
innovative culture if the entrepreneur's actions do not follow the right path. Thus, this paper anticipates reminding the bitter side of entrepreneurial actions and the importance of being aware of these failures to take proper action against them. Possible actions that can be taken against these traps are suggested and demonstrated in Figure 2 as facilitators of entrepreneurial cultures.

Figure 2

Inhibitor versus Facilitator Entrepreneurial Actions in the Formation of an Entrepreneurial Culture

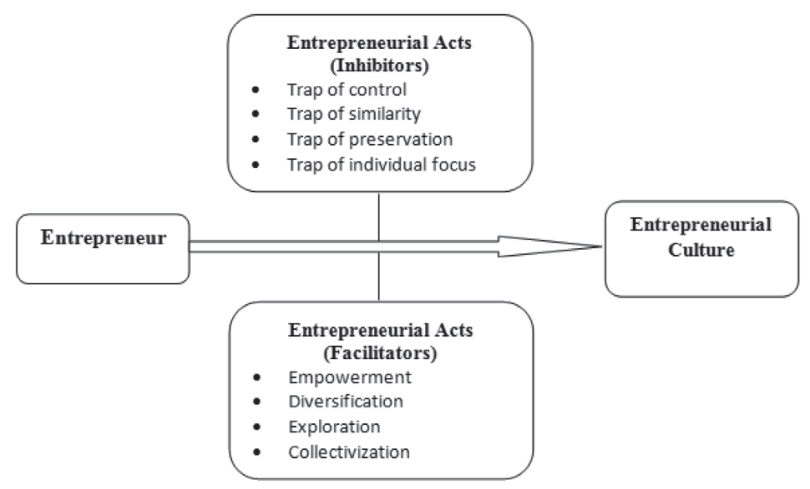

In order not to get caught in the potential traps, empowerment rather than control diversification rather than homogenous selection of members, exploration of opportunities rather than preservation as well as a balance of exploration and exploitation, and focusing on collective identity of the organization rather than on the individual identity of the entrepreneur are suggested as facilitators of an entrepreneurial culture.

More explicitly, entrepreneurs are advised to empower their employees starting with the initial phases of the new venture creation. This way entrepreneur's control will not lead to leader dependence, and thus stress when employees are empowered at later stages. The entrepreneur may still have control and increase the level of delegation incrementally. Moreover, to avoid a homogeneity of perspectives, it is suggested that entrepreneurs emphasize diversity in their recruitment practices while casting their teams. Thirdly, entrepreneurs are advised to keep exploring new ways, processes, products, and ideas while also exploiting the paths and strategies that have proven to work successfully for them. This will help them maintain an innovation oriented culture rather than a preservation oriented one by balancing exploration and exploitation. Finally, a collective spirit in the new venture focusing on team work would be suggested rather than emphasizing a heroic image of the entrepreneur who is seen separate from the team. Through these actions openness to change, flexibility, empowerment, creativity and a collective identity of cultural membership may work together to foster an entrepreneurial culture.

Future studies can empirically investigate separate propositions in this paper. For example, the relationship between recruitment practices that influence diversity and the entrepreneurial culture of the new venture or the relationship between leader de- 
pendence, stress and creativity can be empirically tested. In addition, further studies can investigate the relationship between the heroic perception of an entrepreneur from the employee perspective and entrepreneurial culture in the team. In addition, future studies may benefit from empirically analysing the relationship between entrepreneurs' actions and entrepreneurial cultures by taking into consideration contextual factors such as the industry dynamics and national culture. Another possibility would be taking a longitudinal approach. For example, Martin (2002) suggested that research focusing on organizational culture and creativity and innovation may examine how an innovative culture diminishes over time. In line with that, future research may consider observing the changes in culture (i.e. culture in the new venture formation phase versus growth stage). Finally, entrepreneurial actions in the formation of culture overlap with leadership literature. Further studies can take a stand from the leadership perspective and apply leadership theories like transformational leadership to see the effect on formation and maintenance of innovation oriented entrepreneurial cultures.

\section{References}

Amabile, T.M. (1988). "A Model of Creativity and Innovation in Organizations," in B.M. Staw and L.L. Cummings (eds.). Research in Organizational Behavior: 10: 123-16. Greenwich, CT: JAI Press.

-----, (1996). Creativity in Context. Boulder, CO: Westview Press.

Amabile, T.M., Conti, R., Coon, H., Lazenby, J., and Herron, M. (1996). “Assessing the Work Environment for Creativity,” Academy of Management Journal, 39(5):1154-1184.

Argyris, C. and Schön, D. (1974). Theory in Practice: Increasing Professional Effectiveness. San Francisco: Jossey-Bass.

Ashmore, R.D, Deaux, K., and McLaughlin-Volpe, T. (2004). "An Organizing Framework for Collective Identity: Articulation and Significance of Multidimensionality," Psychological Bulletin, 130(1): 80-114.

Baden-Fuller, C. and Volberda, H.W. (1997). "Strategic Renewal: How Large Complex Organizations Prepare for the Future," International Studies of Management and Organization, 27(2): 95-120.

Baer, M. (2012). "Putting Creativity to Work: The Implementation of Creative Ideas in Organizations," Academy of Management Journal, 55 (5): 1102-1119.

Banaji, M. and Prentice, D. (1994). "The Self in Social Contexts," Annual Review of Psychology, 45: 297-233.

Beaver, G. and Jennings, P. (2005). "Competitive Advantage and Entrepreneurial Power: The Dark Side of Entrepreneurship," Journal of Small Business and Enterprise Development, 12(1): 9-23.

Birkinshaw, J. and Gibson, C. (2004). "Building Ambidexterity into an Organization," MIT Sloan Management Review, 45(4): 47-55.

Blau, P.M. (1977). Inequality and Heterogeneity. New York: Free Press.

Blumentritt, T., Kickul, J., and Gundry, L.K. (2005). "Building an Inclusive Entrepreneurial Culture: Effects of Employee Involvement on Venture Performance and Innovation," The International Journal of Entrepreneurship and Innovation, 6 (2): 77-84.

Boswell, J. (1972). The Rise and Decline of Small Firms. London: Allen and Unwin. 
Brand, A. (1998). "Knowledge Management and Innovation at 3M," Journal of Knowledge Management, 2(1): 17-22.

Burnes, B. (1996). Managing Change: A Strategic Approach to Organisational Dynamics. London: Pitman.

Burpitt, W.J. and Bigoness, W.J. (1997). "Leadership and Innovation among Teams: The Impact of Empowerment," Small Group Research, 28: 414-423.

Camerer, C. and Lovallo, D. (1999). "Overconfidence and Excess Entry: An Experimental Approach," American Economic Review, 89(1): 306-318.

Cameron K.S., and Quinn, R.E. (1999). Diagnosing and Changing Organizational Culture: Bases on the Competing Values Framework. Reading. MA: Addison Wesley.

Capaldo, G., Iandoli, L., Raffa, M., and Zollo, G. (2003). "The Evaluation of Innovation Capabilities in Small Software Firms: A Methodological Approach, "Small Business Economics," 21: 343-354.

Cardon, M.S., Wincent, J., Singh, J., and Drnovsek, M. (2009). "The Nature and Experience of Entrepreneurial Passion," Academy of Management Review, 34(3): 511-532.

Cogliser, C.C. and Brigham, K.H. (2004). "The Intersection of Leadership and Entrepreneurship: Mutual Lessons to be Learned," The Leadership Quarterly, 15: 771-799.

Conger, J.A. (1990). “The Dark Side of Leadership,” Organizational Dynamics, 19: 44-55.

Dawson, C. and Henley, A. (2012). "Over-optimism and Entry and Exit from Self-Employment," International Small Business Journal, 31(8): 938-954.

DeJong, J.P.J. and Den Hartog, D.N. (2007). "How Leaders Influence Employees' Innovative Behaviour," European Journal of Innovation Management, 10(1): 41-64.

Dooley, L. and O'Sullivan, D. (2000). "Systems Innovation Manager," International Journal of Production, Planning and Control, 11(2): 369-379.

Drucker, P. (1985). Innovation and Entrepreneurship. New York, NY: Harper Perennial.

Drummond, H. (2004). “See You Next Week? A Study of Entrapment in a Small Business," International Small Business Journal, 22(5): 487-502.

Dunne, T.C., Aaron, J.R., McDowell, W.C., Urban, D.J., and Geho, P.R. (2016). "The Impact of Leadership on Small Business Innovativeness," Journal of Business Research, 69: 4876-4881.

Earley, P.C. and Mosakowski, E. (2000). "Creating Hybrid Team Cultures: An Empirical Test of Transnational Team Functioning," Academy of Management Journal, 43: 26-49.

Feldman, P.S. (1993). "How Organizational Culture Can Affect Innovation," in L. Hirschmann and C.K.Barnett (eds.). Psychodynamics of Organizations: 85-98. Philadelphia: Temple University Press.

Fisher, R. and Langan-Fox, J. (2009). "Passion, Uncertainty and Successful Entrepreneurial Action," 6th AGSE International Research Conference, Adelaide SA.

Frischer, J. (1993). "Empowering Management in New Product Development Units," Journal of Product Innovation Management, 10: 393-401.

Gartner, W.B. (1988). "Who is an Entrepreneur? is the Wrong Question," American Journal of Small Business, 12(4): 11-32.

------, (1990). "What are We talking about when We Talk About Entrepreneurship?” Journal of Business Venturing, 5(1): 15-28. 
Gilbert, C.G. (2005). "Unbundling the Structure of Inertia: Resource versus Routine Rigidity," Academy of Management Journal, 48 (5): 741-763.

Gupta, V., MacMillan, I.C., and Surie, G. (2004). "Enrepreneurial Leadership: Developing and Measuring a Cross-cultural Construct," Journal of Business Venturing, 19: 241-260.

Gupta, A.K., Smith, K.G., and Shalley, C.E. (2006). "The Interplay between Exploration and Exploitation," Academy of Management Journal, 49(4): 693-706.

Hennessey, B.A. and Amabile, T.M. (1998). "Reward, İntrinsic Motivation, and Creativity," American Psychologist, 53(6): 674-676.

Heunks, F.J. (1998). “Innovation, Creativity and Success," Small Business Economics, 10 (3): 263-272.

Hitt, M.A, Keats, B.W., and DeMarie, S.M. (1998). "Navigating in the New Competitive

Landscape: Building Strategic Flexibility and Competitive Advantage in the 21st Century," Academy of Management Executive, 12(4): 22-42.

Jackson, S.E., May, K.E., and Whitney, K. (1995). "Understanding the Dynamics of Diversity in Decision-making Teams," in R.A. Guzzo and E. Salas (eds.). Team Effectiveness and Decision Making in Organizations. San Francisco: Jossey-Bass: 204-261.

James, L.R., Choi, C.C., Ko, C.H.E., McNeil, P.K., Minton, M.K., Wright, M.A., and Kim, K. (2007). "Organizational and Psychological Climate: A Review of Theory and Research," European Journal of Work and Organizational Psychology, 17(1): 5-32.

Janis, I.L. (1971). “Groupthink,” Psychology Today, 5(6): 43-46.

Jassawalla, A.R. and Sashittal, H.C. (2002). "Cultures that Support Product Innovation Processes," Academy of Management Executive, 16 (3): 42-53.

Jaussi, K.S. and Dionne, S.D. (2003). "Leading for Creativity: The Role of Unconventional Leader Behaviour," The Leadership Quarterly, 14: 475-498.

Jones, T.P. (1972). Creative Learning in Perspective. London: University of London Press.

Judge, W.Q., Fryxell, G.E., and Dooley, R.S. (1997). "The New Task of R\&D Management: Creating Goal-directed Communities for Innovation," California Management Review, 39 (3): 72-85.

Kang, J.H., Solomon, G.T., Choi, D.Y. (2015). “CEOs' Leadership Styles and Managers' Innovative Behavior: Investigation of Intervening Effects in an Entrepreneurial Context," Journal of Management Studies, 52: 531-554.

Kao, J. (1989). Entrepreneurship, Creativity and Organisation. Englewood Cliffs, NJ: Prentice Hall.

Kark, R., Shamir, B., and Chen, G. (2003). "The Two Faces of Transformational Leadership: Empowerment and Dependency," Journal of Applied Psychology, 88(2): 246-255.

Kets DeVries, M.F.R (1985). “The Dark Side of Entrepreneurship," Harvard Business Review 63(6): 160-167. $853-883$

(1996). "The Anatomy of the Entrepreneur: Clinical Observations," Human Relations, 49:

King, N. and Anderson, N. (2002). Managing Innovation and Change: A Critical Guide for Organizations. London: Thomson.

Krause, D.E. (2004). "Influence-based Leadership as a Determinant of the Inclination to Innovate and of Innovation-related Behaviors: An Empirical Investigation," The Leadership Quarterly, 15(1): 79-102. 
Kuratko, D.F. (2007). "Entrepreneurial Leadership in the 21st Century: Guest Editor's Perspective," Journal of Leadership and Organizational Studies, 13(4): 1-11.

Lazarus, R.S. and Folkman, S. (1984). Stress, Appraisal, and Coping. New York: Springer.

Leonard-Barton, D. (1992). "Core Capabilities and Core Rigidities: A Paradox in Managing New Product Development," Strategic Management Journal, 13: 111-125.

Levinthal, D.A. and March, J.G. (1993). "The Myopia of Learning," Strategic Management Journal, 14: $95-112$.

Lipman-Blumen, J. (1992). "Connective Leadership: Female Leadership Styles in the 21st-Century Workplace," Sociological Perspectives, 35(1): 183-203.

March, J. G. (1991). Exploration and Exploitation in Organizational Learning," Organization Science: 2(1): 71-87.

, (1995). "The Future, Disposable Organizations and the Rigidities of Imagination," The Organization, 2: 427-440.

Martin, J. (2002). Organizational Culture: Mapping the Terrain. Thousand Oaks, CA: Sage.

Martins, E.C. and Terblanche, F. (2003). "Building Organisational Culture that Stimulates Creativity and Innovation," European Journal of Innovation Management, 6(1): 64-74.

McLean, L.D. (2005). "Organizational Culture's Influence on Creativity and Innovation: A Review of the Literature and Implications for Human Resource Development," Advances in Developing Human Resources, 7(2): 226-246.

McLeod, P.L., Lobel, S.A., and Cox T.H. (1996). "Ethnic Diversity and Creativity in Small Groups," Small Group Research, 27: 246-264.

Miller, D. (2015). “A Downside to the Entrepreneurial Personality?," Entrepreneurship Theory and Practice," 39: 1-8.

Mintzberg, H. (1979). The Structuring of Organizations. Englewood Cliffs, NJ: Prentice-Hall.

Nystrom, H. (1990). "Organizational Innovation,” in M.A.West and J.L. Farr (eds.). Innovation and Creativity at Work: 143-161. Chichester, England: Wiley.

Ogbonna, E. and Harris, L.C. (2000). "Leadership Style, Organizational Culture and Performance: Empirical Evidence from UK Companies," International Journal of Human Resource Management, 11(4): 766-788.

Parker, S.K. (1998). "Enhancing Role Breadth Self-efficacy: The Role of Job Enrichment and Other Organizational Interventions," Journal of Applied Psychology, 83: 835-852.

Parnes, S.J. (1961). "Effects of Extended Effort in Creative Problem Solving," Journal of Educational Psychology, 52: 117-122.

Peters, T. (1997). The Circle of Innovation: New York: Alfred A. Knopf.

Pettigrew, A.M. (1979). "On Studying Organizational Cultures," Administrative Science Quarterly, 24(4): 570-581.

Pohlmann, M., Gebhardt, C., and Etzkowitz, H. (2005). "The Development of Innovation Systems and the Art of Innovation Management: Strategy, Control and the Culture of Innovation," Technology Analysis and Strategic Management, 17(1): 1-7.

Prahalad, C.K. and Hamel, C. (1990). "The Core Capability of the Corporation," Harvard Business Review, 68(3): 79-91. 
Quinn, R.E. and Rohrbaugh, J. (1983). "A Spatial Model of Effectiveness Criteria: Towards a Competing Values Approach to Organizational Analysis," Management Science, 29: 363-377.

Rafferty, A.E. and Griffin, M.A. (2006). "Perceptions of Organizational Change: A Stress and Coping Perspective," Journal of Applied Psychology, 91(5): 1154-1162.

Rauch, A. and Frese, M. (2007). "Let's Put the Person Back into Entrepreneurship Research: A Metaanalysis on the Relationship between Business Owners' Personality Traits, Business Creation, and Success," European Journal of Work and Organizational Psychology, 16(4): 353-385.

Reich, R.B. (1987). “Entrepreneurship Reconsidered: The Team as Hero," Harvard Business Review 65: 377-383.

Russell, R.D. and Russell, C.J. (1992). "An Examination of the Effects of Organizational Norms, Organizational Structure, and Environmental Uncertainty on Entrepreneurial Strategy," Journal of Management, 18: 639-656.

Schein, E.H. (1983). "The Role of the Founder in Creating Organizational Culture," Organizational Dynamics, 12: 13-28.

-------, (1985). Organizational Culture and Leadership. San Francisco: Jossey-Bass.

Schneider, B. (1987). “The People Make the Place," Personnel Psychology, 40: 437-453.

Schneider, B., Goldstein, H.W., and Smith, D.B. (1995). "The ASA Framework: An Update," Personnel Psychology, 48: 747-779.

Schumpeter, J. (1934). “The Theory of Economic Development," Cambridge, Mass: Harvard University Press.

Sexton, D.L. and Bowman, N. (1985). “The Entrepreneur: A Capable Executive and More,"Journal of Business Venturing, 1(1): 129-140.

Shah, A.K. and Oppenheimer, D.M. (2008). "Heuristics Made Easy: An Effort-reduction Framework," Psychological Bulletin, 134 (2): 207-222.

Shalley, C.E. and Gilson, L.L. (2004). "What Leaders Need to Know: A Review of Social and Contextual Factors that can Foster or Hinder Creativity," The Leadership Quarterly, 15: 3353.

Shamir, B. (1991). "The Charismatic Relationship: Alternative Explanations and Predictions," The Leadership Quarterly, 2: 81-104.

Shane, S. and Venkataraman, S. (2000). "The Promise of Entrepreneurship as a Field of Research," Academy of Management Review, 2: 217-226.

Shimizu, K. and Hitt, M.A. (2004). "Strategic Flexibility: Organizational Preparedness to Reverse Ineffective Strategic Decisions," Academy of Management Executive, 18(4): 44-58.

Slevin, D.P. and Covin, J.G. (1990). "Juggling Entrepreneurial Style and Organizational Structure: How to Get Your Act Together," Sloan Management Review, 31(2): 43-53.

Spreitzer, G.M. (1995). "Psychological Empowerment in the Workplace: Dimensions, Measurement, and Validation," Academy of Management Journal, 38: 1442-1465.

Staw, B.M. (1981). "The Escalation of Commitment to a Course of Action," Academy of Management Review, 6: 577-587.

Tajfel, H. (1978). "Social Categorization, Social Identity, and Social Comparison," in H. Tajfel (ed.). Differentiation between Social Groups: Studies in the Social Psychology of Intergroup Relations: 61-76. London: Academic Press. 
Talbot, R., Cooper, C., and Barrow, S. (1992). "Creativity and Stress," Creativity and Innovation Management, 1(4): 183-193.

Timmons, J. (1999). New Venture Creation. Burr Ridge, IL: Irwin McGraw-Hill.

Trice, H.M. and Beyer, J.M. (1993). The Culture of Work Organizations. Englewood Cliffs, NJ: Prentice Hall

Vallerand, R.J., Blanchard, C., Mageau, G.A., Koestner, R., Ratelle, C., Leonard, M., Gagne, M., and Marsolais, J. (2003). "Les Passions de L'ame: On Obsessive and Harmonious Passion," Journal of Personality and Social Psychology, 85(4): 756-767.

Van Knippenberg, D., Van Knippenberg, B., De Cremer, D., and Hogg, M.A. (2004). "Leadership, Self, and Identity: A Review and Research Agenda," The Leadership Quarterly, 15: 825-856.

Vecchio, R.P. (2003). "Entrepreneurship and Leadership: Common Trends and Common Threads," Human Resource Management Review, 13: 303-327.

Volery, T., Mueller, S., and von Siemens, B. (2015). "Entrepreneur Ambidexterity: A Study of Entrepreneur Behaviours and Competencies in Growth-oriented Small and Medium-sized Enterprises," International Small Business Journal, 33(2): 109-129.

Watson, W.E., Kumar, K., and Michaelson, L.K. (1993). “Cultural Diversity's Impact on Interaction Process and Performance: Comparing Homogeneous and Diverse Task Groups," Academy of Management Journal, 36: 590-602.

West, M.A. and Farr, J.L. (1990). "Innovation at Work," in M.A.West and J.L.Farr (eds.). Innovation and Creativity at Work: Psychological and Organizational Strategies: 3-13. Chichester: Wiley.

Williams, K.Y. and O'Reilly, C.A. (1998). "Demography and Diversity in Organizations: A Review of 40 Years of Research," in B.M. Staw and L.L. Cummings (eds.). Research in Organizational Behavior, 20: 77-140. Greenwich, CT: JAI Press.

Woodman, R.W., Sawyer, J.E., and Griffin R.W. (1993). "Toward a Theory of Organizational Creativity," Academy of Management Review, 18(2): 293-321.

Yamada, J. and Yamashita, M. (2006). "Entrepreneurs' Intentions and Partnership towards Innovation: Evidence from the Japanese Film Industry," Creativity and Innovation Management, 15(3): 258-267.

Zhao, F. (2005). "Exploring the Synergy between Entrepreneurship and Innovation," International Journal of Entrepreneurial Behaviour and Research, 11(1): 25-41. 